\title{
Accountantswetgeving: evaluatie geëvalueerd
}

\section{Roger Dassen}

SAMENVATTING Het lang verwachte kabinetsstandpunt inzake de evaluatie van de accountantswetgeving bevat een aantal goede aanknopingspunten, maar kan op enkele terreinen toch ook kwaliteitsproblemen met zich meebrengen. De auteur geeft zijn zorgen weer op het gebied van onderwijs, kwaliteitsborging, onafhankelijkheid en met name ook de organisatie van en het toezicht op het accountantsberoep. Centraal staat daarbij de vraag of het kabinetsstandpunt voldoende aandacht heeft besteed aan de ontwikkeling naar een brede assurance-functie en de complicaties die hiervan uitgaan voor de genoemde aandachtsgebieden.

\section{Inleiding}

Wat goed is, komt snel! Gegeven de aanzienlijke vertraging waarmee de evaluatie van de accountantswetgeving tot stand is gekomen, is er alle reden om op grond van deze gevleugelde uitspraak eens kritisch te kijken naar de inhoudelijke kwaliteit van het kabinetsstandpunt in dezen, dat uiteindelijk in november 2001 het licht heeft gezien. In deze bijdrage zullen de hoofdpunten van het kabinetsstandpunt tegen het licht worden gehouden, te weten de accountancyopleiding (paragraaf 2), de overige deskundigheidsborging (paragraaf 3 ), het onafhankelijkheidsvraagstuk (paragraaf 4) en ten slotte de organisatie van het accountantsberoep en het toezicht daarop (paragraaf 5). In paragraaf 6 zullen enkele conclusies worden getrokken. Daarbij ligt de nadruk op de vraag of het

Prof. Dr. R. J.M. Dassen RA is partner van Deloitte \& Touche Accountants en tevens hoogleraar Auditing aan de Universiteit Maastricht alsmede de Vrije Universiteit. Hij studeerde economie en accountancy aan de Universiteit Maastricht, waar hij in 1995 promoveerde. kabinet in voldoende mate rekening heeft gehouden met moderne ontwikkelingen op het gebied van business reporting en assurance services, zoals onder meer uiteengezet in International Standard on Assurance Engagements 100 (IFAC, 2000).

\section{Onderwijs}

Eerst dan maar het goede nieuws: het kabinet is tevreden over de opleidingskwaliteit en concludeert dat het minimum opleidingsniveau van de Achtste Richtlijn op dit moment ruim wordt gehaald. Niettemin heeft het kabinet een aantal voorstellen voor onderwijsland. Om te beginnen wil het kabinet een revisie van de toezichtstructuur op het opleidings- en examentraject, tot nu toe, met name vanuit de particuliere historie van het accountancyonderwijs, ingevuld door de Examenbureaus RA en AA alsmede een daarop toeziend Curatorium. Ondanks hun onmiskenbare bijdrage aan de hoog geachte opleidingskwaliteit vindt het kabinet het gewenst om deze in onderwijsland nogal exotische structuur te vervangen door een binnen onderwijsland meer gangbaar toezichtmodel, waarbij sprake is van een verregaande autonomie van de onderwijsinstelling, een redelijk gestandaardiseerde visitatiesystematiek, alsmede een accreditatiesysteem door het (overigens nog op te richten) Nationaal Accreditatieorgaan. Op zichzelf een heldere structuur, waarbinnen het ook niet echt als een verrassing komt dat het kabinet voorstelt om de wettelijke taak van de beroepsorganisaties tot het (doen) verzorgen van de theoretische opleiding te laten vallen. Maar toch zijn er een paar aandachtspunten.

Een eerste aandachtspunt betreft de rol die de beroepsorganisaties hebben ten aanzien van het opleidingstraject. 'Nadere invulling van de opleidingsprogramma's zal (...) in (landelijk) overleg tussen de privaatrechtelijke beroepsorganisaties en onderwijsinstellingen plaatsvinden', zo stelt het kabi- 
net. Het vinden van een goed evenwicht tussen - op zich zeer wenselijke - autonomie van de onderwijsinstellingen enerzijds en voldoende inspraak van de beroepsorganisaties anderzijds, zal nog best een praktische uitdaging inhouden. Gegeven de dynamiek in de omgeving waarin accountants opereren - integratie van IT-systemen, internationalisatie en complexiteit van regelgeving, uitbreiding van de scope naar zaken als maatschappelijke verslaggeving en risk management - lijkt het mij van belang dat de beroepsorganisaties een heldere visie neerleggen ten aanzien van het beroepsprofiel, als basis voor verder door de instellingen in te vullen opleidings- en examenprogramma's. Dit is met name een interessant vraagstuk gegeven de mogelijkheid dat in de toekomst naast de huidige RA- en AA-opleidingen ook andere (particuliere) instellingen zullen worden geaccrediteerd ten behoeve van de opleiding tot certificerend accountant. Waar op dit moment in Nederland het beeld heerst dat de bestaande opleidingen ruim boven de minimumeisen van de Achtste Richtlijn vallen, mag niet worden uitgesloten dat enkele van deze nieuwe aanbieders met name de minimumeisen van deze Achtste Richtlijn als norm zullen gaan hanteren. Dit kan leiden tot een situatie waarbij de betreffende opleiders gaan opleiden tot certificerend accountant, maar niet voor een AA- of RA-titel. Voor de huidige opleiders ontstaat daarbij de vraag of zij ook gaan aanbieden conform de minimumnorm, dan wel maximaal inzetten op kwaliteit en actualiteit van de opleiding, in een goede dialoog met de beroepsorganisaties en gebruikmakend van de toegenomen vrijheidsgraden binnen het nieuwe systeem. Ten slotte moet ik ten aanzien van de praktijkopleiding vaststellen, dat deze in het kabinetsstandpunt tamelijk stiefmoederlijk wordt behandeld. Jammer, te meer daar het belang hiervan alleen maar toeneemt naarmate de beroepsorganisaties verder van de theorieopleidingen worden geplaatst.

\section{Deskundigheidsborging}

Om diezelfde reden, de toenemende complexiteit en diepgang van de vraagstukken waarvoor accountants komen te staan, is het jammer dat het kabinet zich nauwelijks uitlaat over de overige deskundigheidseisen die moeten worden gesteld aan met name de certificerende accountant. Zeker, er wordt voorgesteld om de bestaande eisen inzake de permanente educatie en de collegiale toetsing wettelijk te verankeren. Maar is daarmee dan de zorg in het Berenschot-rapport, dat de deskundigheid 'niet voldoende toekomstbestendig geborgd is', weggenomen? Ik kan het mij niet voorstellen. Door de steeds verdergaande technocratisering van de regelgeving op het gebied van verslaggeving en accountantscontrole en de steeds complexere economische realiteit waarover bedrijven verantwoording moeten afleggen, wordt accountancy in toenemende mate een zeer gespecialiseerd vakgebied. Dat stelt niet alleen verdergaande (en vooral minder vrijblijvende) eisen aan permanente educatie, maar vooral ook aan het ervaringsniveau van de betrokken specialisten. Het is dan ook buitengewoon jammer dat de ervaringseisen die door het Koninklijk NIVRA zijn gesteld als voorwaarde voor het behoud van certificeringbevoegdheid, door het kabinet aan de kant zijn geveegd. Met een beroep op artikelen 43 en 49 van het EG-verdrag wordt geconcludeerd dat met de invoering van ervaringseisen 'de toegang tot de certificerende functie zowel voor Nederlandse als buitenlandse accountants namelijk onnodig belemmerd' zou worden. Onbegrijpelijk. Waar het kabinet in haar inleidende bespiegelingen rept over het 'grote maatschappelijke belang' dat aan accountants wordt gehecht, of refereert aan het belang van betrouwbare accountantsverklaringen voor het optimaal werken van de kapitaalmarkt, wordt het kwaliteitsbelang ondergeschikt gemaakt aan een nogal exotisch mededingingsargument. Uit een nadere toelichting blijkt dat het kabinet vooral behoefte heeft aan herkenbaarheid van de certificerende functie, 'om aan het maatschappelijke verkeer duidelijk te maken in welke hoedanigheid zij optreden en aan welke wettelijke onafhankelijkheids- en deskundigheidseisen zij ten gevolge daarvan dienen te voldoen'. Jammer dat het kabinet vervolgens verzuimt om aan die specifieke deskundigheidseisen voor certificerende accountants concrete invulling te geven, anders dan via een bescheiden eis op het gebied van de permanente educatie.

\section{Onafhankelijkheid}

Op dit vlak sluit het kabinet voor een belangrijk gedeelte aan bij de voorstellen van de Europese Commissie. In het kabinetsstandpunt wordt in dit kader de hoofdlijn van de Europese aanbeveling aangehaald, waarbij wordt opgemerkt dat het kabinet het wenselijk acht om de in deze aanbeveling opgenomen fundamentele principes om te zetten in nationale wetgeving. Min of meer in lijn hiermee is de kern van het kabinetsvoorstel in dit verband, dat in de accountantswet een tweetal beroepsethische normen wordt opgenomen voor accountants, namelijk een algemene plicht tot onpartijdigheid en een bepaling dat de accountant andere opdrachten bij een controlecliënt 
mag accepteren, mits hij kan aantonen dat het risico van afhankelijkheid niet significant is, hetgeen moet blijken uit een periodiek te verrichten onafhankelijkheidstoets. Het venijn van het kabinetsstandpunt zit hem evenwel in een tweetal specifieke verbodsbepalingen, te weten het verbod op het opmaken van de jaarrekening en het verzorgen van de financiële administratie voor een controlecliënt. Het onafhankelijkheidsrisico van dergelijke combinaties acht het kabinet maatschappelijk onaanvaardbaar, en daarmee gaat het kabinet aanzienlijk verder dan de Europese Commissie, die een dergelijk verbod alleen voor 'public interest entities' had opgenomen. Door dit verbod nu uit te breiden naar alle entiteiten ontstaat een aanzienlijke lastenverzwaring voor met name het $\mathrm{MKB}$, terwijl het onafhankelijkheidsrisico in dit verband zeker genuanceerd kan worden. Natuurlijk is het niet de bedoeling dat een accountant zijn eigen werk controleert. Maar wat is er op tegen wanneer een accountant op basis van een volledig door de cliënt zelf vervaardigde en afgesloten administratie de cijfers rubriceert in het juiste 'jaarrekening-format'? Zeker wanneer de cliënt zelf verantwoordelijk is voor alle posten waarbij oordeelsvorming van belang is (denk aan voorzieningen, impairment tests en dergelijke), is het risico van de combinatie van een 'kale' samenstellingsopdracht en accountantscontrole ver gezocht. Voor het tweede verbod - de combinatie van het voeren van administratie en controle van de jaarrekening - kan ik zeker begrip opbrengen. Vraag is echter hoe ver deze verbodsbepaling strekt. Met andere woorden, bedoelt het kabinet hiermee iedere vorm van administratieve ondersteuning bij een controlecliënt te verbieden (dat lijkt mij nogal drastisch, zeker weer in de MKB-sfeer), of geldt het verbod slechts de integrale verzorging van de financiële administratie?

\section{De organisatie van het accountantsberoep en het toezicht}

Wellicht de meest drastische wijzigingen van het kabinetsstandpunt hebben betrekking op de organisatie van het accountantsberoep. Niet onverwacht, want de maatschappelijke behoefte aan de invulling van een toezichtfunctie ten aanzien van het accountantsberoep is manifest. Anders dan in de meeste andere landen en ook anders dan bij de meeste andere vrije beroepen, heeft het kabinet ervoor gekozen om een nieuw zelfstandig bestuursorgaan (ZBO) in te stellen met verantwoordelijkheid voor de uitvoering van en het toezicht op de wet- en regelgeving met betrekking tot de deskundigheid, onafhankelijkheid en herkenbaarheid van certificeringbevoegde accoun- tants. Dit houdt in dat het nieuwe ZBO de bepalingen op het gebied van permanente educatie, onafhankelijkheid, collegiale toetsing en het gebruik van de functienaam zal vaststellen voor de betreffende categorie van accountants. Wij zullen moeten afwachten hoe dit model in de praktijk gaat werken. Wie gaat straks in de praktijk daadwerkelijk de uitvoering ter hand nemen? Gaat dat echt gebeuren door een zelfstandige organisatie, los van de huidige beroepsorganisaties? Hoe groot zal de invloed van de beroepsbeoefenaren op de uitvoering nog zijn? Welke ruimte zal er nog zijn voor de talrijke accountants die zich op dit moment inzetten binnen het verband van de beroepsorganisaties in het kader van vaktechnische ontwikkeling, beroepsreglementering, permanente educatie en peer review? Het is nog niet allemaal duidelijk. En de vraag rijst waarom niet is gekozen voor een model waarin zelfregulering en toezicht zijn gecombineerd. Zoals in het model dat door het NIVRA is voorgesteld en dat ook in het buitenland veelvuldig voorkomt, waarbij een publiekrechtelijke beroepsorganisatie de uitvoering verricht en een breed samengesteld onafhankelijk orgaan toezicht uitoefent.

Wordt derhalve voor de certificerende werkzaamheden (door het kabinet op het eerste oog tamelijk eng gedefinieerd als 'het afgeven van een accountantsverklaring bij een verantwoording uit hoofde van vrijwillige en verplichte controles') het ene extreem betrokken (einde van de zelfregulering), voor de nietcertificerende werkzaamheden neigt het kabinet naar een ander extreem. Die zouden namelijk niet langer onder een publiekrechtelijke beroepsorganisatie moeten vallen, maar privaatrechtelijk geregeld moeten worden. In dit kader suggereert het kabinetsstandpunt dat NIVRA en NOVAA zich zouden kunnen ontwikkelen tot privaatrechtelijke beroepsorganisaties en zich wellicht meer kunnen richten op de accountantswerkzaamheden die geen 'publiek karakter' hebben, zoals management consultancy, forensische accountancy en milieuaccountancy. Die laatste voorbeelden zijn op zijn minst opmerkelijk te noemen. Want zowel de forensische als de milieuaccountancy (in het kader van maatschappelijke verslaggeving) ontwikkelen zich, gemeten aan de aandacht in de pers voor beide vraagstukken, steeds nadrukkelijker tot werkgebieden met een publiek karakter! En ik denk dat het beter zou zijn om ook voor dit soort werkzaamheden de kwaliteitswaarborgen van een publiekrechtelijke beroepsorganisatie, waaronder de Gedrags- en Beroepsregels en de relevante onderdelen van de Richtlijnen voor de Accountantscontrole, te handhaven. Immers, door het loslaten van de 
publiekrechtelijke status zal waarschijnlijk ook de wettelijke bescherming van de aanduiding 'accountant' komen te vervallen. Zodat een heel leger accountants zal ontstaan op gebieden als 'forensic' en 'milieu', zonder een noodzakelijke inbedding binnen de kwaliteitskaders zoals wij die op dit moment kennen. Zeker gegeven de evolutie van de traditionele certificerende functie naar het brede scala aan assurance services ontstaat daarmee de vraag, of het kabinetsvoorstel voldoende toekomstbestendig is. Toezichthouders als Securities and Exchange Commission-voorzitter Pitt en Stichting Toezicht Effectenverkeer-lid Koster hebben recent aan de orde gesteld, dat binnen het kader van moderne business reporting de jaarrekening weliswaar een belangrijke plaats inneemt, maar daarin niet meer alleen staat. Verslaggeving over de kwaliteit van processen, over risk management, over prospectieve informatie en over 'sustainability' zal in toenemende mate voorzien in de behoefte aan meer tijdigheid en meer diversiteit in de informatieverschaffing door ondernemingen, langs de lijnen die onder meer het Jenkins Committee in de jaren negentig heeft uitgezet. Assurance over dit soort vraagstukken, gecodificeerd in de onlangs verschenen International Standard on Assurance Engagements 100 (IFAC, 2000), zal in dat licht waarschijnlijk steeds belangrijker worden. En inbedding van deze maatschappelijk relevante activiteiten binnen het meer verplichtende en kwaliteitsborgende kader van een publiekrechtelijke beroepsorganisatie is dan ook juist nu gewenst.

\section{Samenvatting en conclusie}

Het kabinet heeft in haar standpunt ten aanzien van de evaluatie van de accountantswetgeving een aantal duidelijke keuzes gemaakt. Verankering van belangrijke uitgangspunten rondom het accountantsberoep in wetgeving leidt zeker tot verheldering, en de stroomlijning van het toezicht op het onderwijs past ook geheel binnen de huidige tijd. Daarnaast wordt in de onafhankelijkheidsdiscussie zoveel mogelijk aansluiting gezocht bij de aanbevelingen van de Europese Commissie, en ook dat valt ver te prefereren boven pogingen om een andere koers te varen, zoals die in enkele andere EU-landen kunnen worden waargenomen. Toch kan er ook kritiek worden geuit op dit kabinetsstandpunt, dat zich voornamelijk heeft geconcentreerd op de certificerende functie. Door deze insteek wordt weliswaar de belangrijkste huidige vorm van assurance geregeld (helaas in een $\mathrm{ZBO}$ vorm die breekt met het prima functionerende model van zelfregulering), maar wordt onvoldoende ingespeeld op actuele ontwikkelingen rondom business reporting en assurance. Deze eng gedefinieerde visie blijkt zowel uit de voorstellen rondom opleiding, die kwaliteitsrisico's met zich mee kunnen brengen met name ten aanzien van het inspelen op nieuwe ontwikkelingen, als uit de voorstellen rondom de toekomstige beroepsorganisatie, die een mogelijke kwaliteitserosie tot gevolg kunnen hebben voor de niet-certificerende werkzaamheden. Met betrekking tot het onafhankelijkheidsvraagstuk wordt opgemerkt dat op één punt belangrijk wordt afgeweken van de aanbevelingen van de Europese Commissie, namelijk door het verbod bij alle controlecliënten (derhalve niet alleen voor de public interest entities) op de combinatie van controle enerzijds en administratieve ondersteuning dan wel ondersteuning bij het samenstellen van de jaarrekening anderzijds. Met name binnen het MKB zal dit standpunt leiden tot een situatie waarbij een controlerende en een ondersteunende accountant naast elkaar zullen opereren, hetgeen tot een aanzienlijke lastenverzwaring kan leiden. Ten slotte is het jammer dat het kabinet het grote belang van de certificerende functie niet tot uitdrukking heeft gebracht in ervaringseisen specifiek voor die functie. Dat kwaliteitseisen in dit kader ondergeschikt worden gemaakt aan mededingingseisen is niet verenigbaar met de cruciale rol die het kabinet toedicht aan de certificerende functie voor het maatschappelijk bestel.

\footnotetext{
Literatuur

American Institute of Certified Public Accountants, (1994), Improving Business Reporting - A Customer Focus.

Dassen, R.J.M., (2002), Kabinet brengt kwaliteit onderwijs ernstig in gevaar, in: Het Financieele Dagblad, 9 januari.

European Commission, (2000), Statutory Auditors' Independence in the EU; A Set of Fundamental Principles, December.

International Federation of Accountants, (2000), International Standards on Assurance Engagements 100.

Kabinetsstandpunt Evaluatie Accountantswetgeving, november 2001.
} 